\author{
A.R. Yeshkeyev \\ Buketov Karaganda state university, Kazakhstan \\ (E-mail: modth1705@mail.ru)
}

\title{
Model-theoretical questions of the Jonsson spectrum
}

\begin{abstract}
In this paper, new concepts are defined in the framework of the study of Jonsson spectrum. We consider a spectrum with respect to the concept of cosemanticness, which is a generalization of elementary equivalence in the class of inductive, generally speaking, incomplete theories. Also, with the help of Jonsson spectrum, the actual directions of the study of Jonsson theories and their model classes are determined, namely, the study of classical questions of model theory, such as the completeness, model completeness, model companion of within the framework of the above conditions, which define a fairly wide subclass of inductive theories, and which Jonsson theories. Therefore, in studying the model-theoretical properties of Jonsson spectrum, we need to clarify the definition of those concepts that naturally arise when we move from the concept of elementary equivalence to the concept of cosemanticness, moreover, both theories and models. Some model-theoretical properties of the Jonsson spectrum are considered. When considering the Jonsson spectrum, all the tasks that are posed in this article make sense and their solution can be useful for solving related problems, because this problem is actively studied in the field of Jonsson theories.
\end{abstract}

Keywords: Jonsson theory, Jonsson spectrum, cosemanticness, completeness, similarity.

This article is devoted to the study of model-theoretical questions of the Jonsson spectrum. The concept of the Jonsson spectrum arose in the study of the Jonsson invariants of abelian groups and modules [1, 2]. This problem arises in the study of an arbitrary Jonsson theories of an arbitrary signature. It is well known that Jonsson theories, generally speaking, are not complete theories. In this regard, it becomes interesting to generalize the concept of elementary equivalence of two models. The role of this generalization is played by the concept of cosemanticness of two models. The cosemantic nature of models is a consequence of the cosemantic nature of Jonsson theories to the model classes of which these models belong. In connection with the concept of cosemantics, the question arises of the completeness of the theories under consideration, as well as their perfectness. Moreover, as is known by virtue of the criterion of perfectness $[3 ; 158]$ Jonsson theories, if the Jonsson theory is perfect, the class of its existentially closed models is an elementary class. Perfect Jonsson theories are wellarranged in the sense that their semantic invariant, namely their center, is a model companion. But nevertheless, if we move from the Jonsson theory to an arbitrary Jonsson spectrum of one of the models of this theory, then this spectrum can contain both perfect and imperfect theories. Therefore, in studying the model-theoretical properties of Jonsson spectrum, we need to clarify the definition of those concepts that naturally arise when we move from the concept of elementary equivalence to the concept of cosemantics, moreover, both theories and models. It is clear that it would not be easy to proceed directly to the study of Jonsson spectrum in a general form due to the above difficulties. In this regard, we propose in a certain way to limit the studied class of problems to the framework that seems to us natural and interesting from the point of view of this problem.

Thus, the main purpose of this article is to identify certain concepts that are new in the study of Jonsson spectrum, and with their help we want to determine the actual directions of the study of Jonsson theories and their model classes.

All the above concepts are directly related to the study of Jonsson theories and their classes of models. This issue is being actively studied and in this article we cannot immediately cover all areas of these studies. Nevertheless, here is a list of links that are related to the concepts considered in this article [4-15].

We give the necessary definitions. 
Let $\sigma$ be some signature, $L$ be the set of all formulas of signature $\sigma$, i. e. a language of this signature. Let $\mathcal{A}$ be an arbitrary model of signature $\sigma$, i. e. $\mathcal{A} \in \operatorname{Mod} \sigma$. Let us call the Jonsson spectrum of model $\mathcal{A}$ a set:

$$
J \operatorname{Sp}(\mathcal{A})=\{T \mid T \text { is Jonsson theory in language } \sigma \text { and } \mathcal{A} \in \operatorname{Mod} T\} .
$$

Denote by $\operatorname{JSp}_{\Gamma}(\mathcal{A})=\{T \mid T$ is $\Gamma$-complete Jonsson theory in language $\sigma$ and $\mathcal{A} \in \operatorname{ModT}\}$, where $\Gamma$ is type of a prenex prefix after reduction a set of all sentences of signature $\sigma$ to a prenex normal form of.

The relation of cosemanticness on a set of theories is an equivalence relation. Then $J S p(\mathcal{A}) / \bowtie$ is the factor set of Jonsson spectrum of the model $\mathcal{A}$ with respect to $\bowtie$. Similarly, we can consider the factor set $J S p_{\Gamma}(\mathcal{A}) / \bowtie$.

Let $[T] \in J \operatorname{Sp}(\mathcal{A}) / \bowtie$. Since every theory $\Delta \in[T]$ has $\mathcal{C}_{\Delta}=\mathcal{C}_{T}$, then the semantic model of class $[T]$ will be called the semantic model of a theory $T: \mathcal{C}_{[T]}=\mathcal{C}_{T}$. The center of Jonsson class $[T]$ will be called an elementary theory $[T]^{*}$ of its semantic model $\mathcal{C}_{[T]}$, i. e. $[T]^{*}=\operatorname{Th}\left(\mathcal{C}_{[T]}\right)$ and $[T]^{*}=\operatorname{Th}\left(\mathcal{C}_{\Delta}\right)$ for every $\Delta \in[T]$.

Denote by $E_{[T]}=\bigcup_{\Delta \in[T]} E_{\Delta}$ the class of all existentially closed models of class $[T] \in J S p(\mathcal{A}) / \bowtie$. Note that $\bigcap_{\Delta \in[T]} E_{\Delta} \neq \varnothing$, since at least for every $\Delta \in[T]$ we have $\mathcal{C}_{[T]} \in E_{\Delta}$.

Let $\mathcal{A}$ and $\mathcal{B}$ are models of the same signature.

Definition 1 . We will say that a model $\mathcal{A}$ is Jonsson elementarily equivalent to a model $\mathcal{B}(\mathcal{A} \equiv \bar{J} \mathcal{B})$ if $J \operatorname{Sp}(\mathcal{A})=J S p(\mathcal{B})$.

Considering the factorization, we can give the following definition.

Definition 2. We say that a model $\mathcal{A}$ is $J S p$-cosemantic to a model $\mathcal{B}(\mathcal{A} \underset{J S p}{\bowtie} \mathcal{B})$ if $J S p(\mathcal{A}) / \bowtie=$ $J S p(\mathcal{B}) / \bowtie$. Accordingly, we say that a model $\mathcal{A}$ is $J S p$-cosemantic to a model $\mathcal{B}$ regarding $\Gamma$ and write down it $\mathcal{A} \underset{J S p}{\stackrel{\Gamma}{\bowtie}} \mathcal{B}$ if $J S p_{\Gamma}(\mathcal{A}) / \bowtie=J S p_{\Gamma}(\mathcal{B}) / \bowtie$.

Definition 3. The class $[T] \in J S p(\mathcal{A}) / \bowtie$ is called elementarily closed if $\forall[T]^{\prime} \in J S p(\mathcal{A}) / \bowtie:[T]^{\prime} \neq$ $[T] \Rightarrow \Rightarrow E_{[T]} \cap E_{[T]^{\prime}}=\emptyset$. Definition 4. The class $[T] \in J S p(\mathcal{A}) / \bowtie$ is called locally convex if $T h_{\forall \exists}\left(\bigcap_{\Delta \in[T]} E_{\Delta}\right)$ is a Jonsson theory and convex if $T h_{\forall \exists}(A) \in J S p(\mathcal{A})$.

Definition 5. The class $[T] \in J S p(\mathcal{A}) / \bowtie$ is called companion-convex if the theory $\nabla=T h_{\forall \exists}\left(\bigcap_{\Delta \in[T]} E_{\Delta}\right)$ is a Jonsson theory and has a model companion.

We can define the completeness of the class $[T]$ as follows (Definition 4), and all four types of completeness are independent of each other and can combine. An interesting problem is the transfer of results from the Jonsson theory to the Jonsson spectrum, when the completeness of the Jonsson theory is replaced by the following types of completeness and their combinations.

Definition 6 . The class $[T]$ is called a $\Gamma$-complete class if the following conditions are true:

1) $\forall \mathcal{A}, \mathcal{B} \in E_{[T]}, \mathcal{A} \equiv_{\Gamma} \mathcal{B}$;

2) $\forall \mathcal{A}, \mathcal{B} \in E_{[T]}, \mathcal{A} \underset{J S p}{\bowtie} \mathcal{B}$ and $\forall \Delta \in[T], \Delta-\Gamma$-complete.

3) $\forall \varphi \in \Gamma, \forall \Delta \in[T], \Delta \vdash \varphi$ or $\Delta \vdash \neg \varphi \Leftrightarrow \forall \mathcal{A}, \mathcal{B} \in \operatorname{Mod} \Delta, \forall \Delta \in[T], \mathcal{A} \equiv_{\Gamma} \mathcal{B}$;

4) $\forall \varphi \in \Gamma, \forall \mathcal{A}, \mathcal{B} \in E_{[T]}, \mathcal{A}=\varphi \Leftrightarrow \mathcal{B}=\varphi$.

It is well known that the concepts of completeness and model completeness do not coincide, but as shown by [3] in the case of a perfect Jonsson theory, these concepts coincide for the Jonsson theory under consideration. Therefore, in going over to the problem of the Jonsson spectrum, we must take into account that in the case of an imperfect class these concepts do not coincide.

Definition 7 . The class $[T]$ is model complete $\leftrightharpoons \forall \Delta \in[T], \Delta$ is model complete. 
Theorem 1. The class $[T]$ is model complete, if $\forall \mathcal{A}, \mathcal{B} \in E_{[T]}, \forall$ monomorphism $f: \mathcal{A} \rightarrow \mathcal{B}$ is elementary if and only if $\forall \varphi \in L, \exists \psi \in \forall \cap \exists:[T] \vdash(\varphi \sim \psi)[T] \vdash(\varphi \sim \psi) \leftrightharpoons \forall \Delta \in[T], \Delta \vdash(\varphi \sim \psi)$.

Lemma 1. If $\Delta \in[T]$ and $\Delta$ is imperfect, then $\exists \mathcal{B} \in E_{\Delta}, \mathcal{B} \in E_{\Delta}$ for some $\Delta^{\prime} \in[T]$.

Definition 8. $[T]_{1},[T]_{2}$ existentially mutually model complete $\left([T]_{1} \leftrightarrow[T]_{2}\right)$ if $\forall \mathcal{B} \in E_{[T]_{1}}$, $\exists \mathcal{B}^{\prime} \in E_{[T]_{2}}: \mathcal{B} \cong \mathcal{B}^{\prime}$ and the converse is true.

Lemma 2. $[T]_{1} \leftrightarrow[T]_{2} \Leftrightarrow T h_{\forall}\left(C_{[T]_{1}}\right)=T h_{\forall}\left(C_{[T]_{2}}\right)$.

Let us consider some properties of the Jonsson spectrum at fixed completeness (a special case of Definition $6(2))$.

Let $\sigma$ be an arbitrary signature, $\mathcal{A} \in \operatorname{Mod} \sigma, J \operatorname{Sp}(\mathcal{A}) / \bowtie, \mathcal{A} \in \operatorname{ModT}$;

$\operatorname{Mod}[T]=\left\{\mathcal{A} \in \operatorname{Mod} \sigma \mid \mathcal{A} \models T_{i}, \forall T_{i} \in[T]\right\}$.

$\operatorname{Mod}(\operatorname{JSp}(\mathcal{A}))=\left\{\mathcal{B} \in \operatorname{Mod} \sigma|\mathcal{B}|=T_{j}, \forall T_{j} \in J \operatorname{Sp}(\mathcal{A})\right\}$.

$\operatorname{Mod}(J \operatorname{Sp}(\mathcal{A}) / \bowtie)=\{\mathcal{B} \in \operatorname{Mod} \sigma \mid \mathcal{B}=[T], \forall[T] \in J \operatorname{Sp}(\mathcal{A}) / \bowtie\}$.

The $E_{T}$ is elementary class $\Leftrightarrow T$ has a model companion.

Definition 9. $[T]$ has a model companion if any $E_{T_{i}}$ are an elementary class, $T_{i} \in[T]$.

$\mathcal{A} \underset{J S p}{\bowtie} \mathcal{B} \Leftrightarrow J S p(\mathcal{A}) / \bowtie=J S p(\mathcal{B}) / \bowtie$.

$J \operatorname{Sp}(\mathcal{A}) / \bowtie=\{T \mid T-$ Jonsson theory, $\mathcal{A} \models T\}$.

The $[T]$ is complete $\rightleftharpoons \forall \mathcal{A}, \mathcal{B} \in E_{[T]}, \mathcal{A} \underset{J S p}{\bowtie} \mathcal{B}$.

$E_{[T]}=\bigcup_{i \in I} E_{T_{i}}$.

The $[T]$ is perfect $\rightleftharpoons C_{[T]}$ is saturated.

The $[T]$ is $\forall \exists$-complete $\rightleftharpoons \forall \mathcal{A}, \mathcal{B} \in E_{[T]}, \mathcal{A} \underset{J S p}{\stackrel{\forall}{\otimes}} \mathcal{B}$.

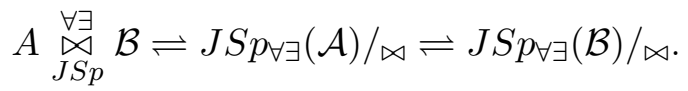

$J S p_{\forall \exists}(\mathcal{A}) / \bowtie=\{T \mid T-\forall \exists-$ complete Jonsson theory, $\mathcal{A}=T\}$

Recall the definitions [3] of syntactic and semantic similarity of Jonsson theories.

Definition 10. Let $T_{1}$ and $T_{2}$ are arbitrary Jonsson theories. We say, that $T_{1}$ and $T_{2}$ are Jonsson's syntactically similar, if exists a bijection $f: E\left(T_{1}\right) \longrightarrow E\left(T_{2}\right)$ such that

1) restriction $f$ to $E_{n}\left(T_{1}\right)$ is isomorphism of lattices $E_{n}\left(T_{1}\right)$ and $E_{n}\left(T_{2}\right), n<\omega$;

2) $f\left(\exists v_{n+1} \varphi\right)=\exists v_{n+1} f(\varphi), \varphi \in E_{n+1}(T), n<\omega$;

3) $f\left(v_{1}=v_{2}\right)=\left(v_{1}=v_{2}\right)$.

Definition 11. The pure triple $\langle C, A u t C, S u b C\rangle$ is called the Jonsson semantic triple, where $C$ is semantic model of $T, A u t C$ is the automorphism group $C, S u b C$ is a class of all subsets of the carrier $C$, which are carriers of the corresponding is existentially-closed submodels of $C$.

Definition 12. Two Jonsson theories $T_{1}$ and $T_{2}$ are called Jonsson's semantically similar if their Jonsson semantic triples are isomorphic as pure triples.

Given these definitions, we define syntactic and semantic similarities of the Jonsson spectrum.

Definition 13. Let $\mathcal{A} \in \operatorname{Mod} \sigma_{1}, \mathcal{B} \in \operatorname{Mod} \sigma_{2},[T]_{1} \in J \operatorname{Sp}(\mathcal{A}) /_{S},[T]_{2} \in J S p(\mathcal{B}) / \bowtie$. We say that the class $[T]_{1}$ is $J$-syntactically similar to class $[T]_{2}$ and denote $[T]_{1} \underset{\rtimes}{S}[T]_{2}$ if for any theory $\Delta \in[T]_{1}$ there is theory $\Delta^{\prime} \in[T]_{2}$ such that $\Delta \stackrel{S}{\rtimes} \Delta^{\prime}$.

Definition 14. The pure triple $\left\langle C, \operatorname{Aut}(\mathcal{C}), \bar{E}_{[T]}\right\rangle$ is called the $J$-semantic triple for class $[T] \in J S p(A) / \bowtie$, where $C$ is the semantic model of $[T]$, AutC is the group of all automorphisms of $C$, $\bar{E}_{[T]}$ is the class of isomorphically images of all existentially closed models of $[T]$.

Definition 15. Let $\mathcal{A} \in \operatorname{Mod} \sigma_{1}, \mathcal{B} \in \operatorname{Mod} \sigma_{2},[T]_{1} \in J \operatorname{Sp}(\mathcal{A}) / \bowtie,[T]_{2} \in J \operatorname{Sp}(\mathcal{B}) / \bowtie$. We say that the class $[T]_{1}$ is $J$-semantically similar to class $[T]_{2}$ and denote $[T]_{1} \underset{S}{\rtimes}[T]_{2}$ if their semantically triples are isomorphic as pure triples.

In the case when it is possible to determine a sufficiently good geometry on the subsets of the semantic model of a class, we can use the technique of strongly minimal Jonsson sets. If we consider 
the enrichment, which will be hereditary, then we can consider the technique of central types, which form an essential base in this geometry.

To determine pregeometry and, accordingly, geometry for the Jonsson spectrum, we will work with subsets of the semantic model of each cosemanticness class of a given Jonsson spectrum. The following definitions are given for fixed subsets $X, Y, A, B$ of some semantic model $\mathcal{C}$ of the fixed class $[T] \in J \operatorname{Sp}(\mathcal{A}) / \bowtie$.

The following definitions (16-28) are taken from [11]. These definitions are consistent with the above conventions regarding the subsets of the semantic model of each class of cosemanticness of a given Jonsson spectrum.

Definition 16. If $(X, c l)$ is a Jonsson pregeometry, we say that $A$ is Jonsson independent if $a \notin \operatorname{cl}(A \backslash\{a\})$ for all $a \in A$ and that $B$ is a $J$-basis for $Y$ if $B \subseteq Y$ is $J$-independent and $Y \subseteq \operatorname{acl}(B)$.

Definition 17. We say that a $J$-pregeometry $(X, c l)$ is $J$-geometry if $\operatorname{cl}(\emptyset)=\emptyset$ and $\operatorname{cl}(\{x\})=\{x\}$ for any $x \in X$.

If $(X, c l)$ is a $J$-pregeometry, then we can naturally define a $J$-geometry. Let $X_{0}=X \backslash \operatorname{cl}(\emptyset)$. Consider the relation $\sim$ on $X_{0}$ given by $a \sim b$ iff $\operatorname{cl}(\{a\})=\operatorname{cl}(\{b\})$. By exchange, $\sim$ is an equivalence relation. Let $\widehat{X}$ be $X_{0} / \sim$. Define $\widehat{c l}$ on $\widehat{X}$ by $\widehat{c l}(A / \sim)=\{b / \sim: b \in \operatorname{cl}(A)\}$.

Definition 18. Let $(X, c l)$ be $J$-pregeometry. We say that $(X, c l)$ is trivial if $c l(A)=Y_{a \in A} c l\{a\}$ for any $A \subseteq X$. We say that $(X, c l)$ is modular if for any finite-dimensional closed $\operatorname{Jim}(A \cup B)=$ $=\operatorname{Jdim}(A)+J \operatorname{dim}(B)--J \operatorname{dim}(A \cap B)$.

We say that $(X, c l)$ is locally modular if $\left(X, c_{a}\right)$ is modular for some $a \in X$.

Definition 19. We say that $(X, c l)$ is modular if for any finite-dimensional closed $A, B \subseteq X$

$$
\operatorname{dim}(A \cup B)=\operatorname{dim} A+\operatorname{dim} B-\operatorname{dim}(A \cap B)
$$

Definition 20. If $X=\mathcal{C}$ and $(X, c l)$ is a modular, then the Jonsson theory $T$ is called modular.

We work actually with the following types of sets.

Definition 21. Let $X \subseteq \mathcal{C}$. We will say that a set $X$ is $\nabla$-cl-Jonsson subset of $C$, if $X$ satisfies the following conditions:

1) $X$ is $\nabla$-definable set (this means that there is a formula from $\nabla$, the solution of which in the $\mathcal{C}$ is the set $X$, where $\nabla \subseteq L$, that is $\nabla$ is a view of formula, for example $\exists, \forall, \forall \exists$ and so on.);

2) $\operatorname{cl}(X)=M, M \in E_{T}$, where $c l$ is some closure operator defining a pregeometry over $\mathcal{C}$ (for example $c l=a c l$ or $c l=d c l$ ).

Definition 22. An enrichment $\bar{T}$ of the Jonsson theory $T$ is said to be permissible if any $\nabla$-type (it mean that $\nabla$ subset of language $L_{\sigma}$ and any formula from this type belongs to $\nabla$ ) in this enrichment

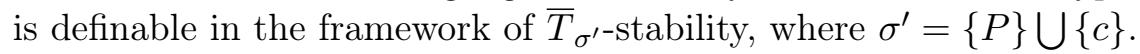

Definition 23. The Jonsson theory is said to be hereditary, if in any of its permissible enrichment, any expansion of it in this enrichment will be Jonsson theory.

Let $S_{\nabla}^{(1)}(X)$ be the set of all complete 1-types over the set $X$, formulas which belong to $\nabla$. Let $X \subseteq M, M \in E_{T}$.

Definition 24. Type $p \in S_{\nabla}^{(1)}(X)$ is called essential if for any set $Y, Y \subseteq N, N \in E_{T}$, such that $X \subseteq Y$ in $T$ exists only unique type $q \in S_{\nabla}^{(1)}(Y)$ and the type $q$ is a $J$-nonforking extension of type $p$.

Let $p, q \in S_{\nabla}^{(1)}(X), \mathfrak{A} \in E_{T}$ and $X \subseteq A$. The relation $p \leq_{A} q$ is means that for any model $\mathfrak{B} \in E_{T}$, such that $\mathfrak{B} \supseteq \mathfrak{A}$, from the realizability of $q$ in $B \backslash A$ implies the realizability of $p$ in $B \backslash A$. The relation $p \equiv q$ means that for any model $\mathfrak{A} \in E_{T}, X \subseteq A$, has $p \leq_{A} q$ and $q \leq_{A} p$. We denote the set $\left\{q \mid q \in S_{\nabla}^{(1)}(X), p \equiv q\right\}$ by $[p]$, and the set $\left\{[p] \mid p \in S_{\nabla}^{(1)}(X)\right\}$ denote by $S_{\nabla}^{(1)}[X]$. We write $[p] \leq_{A}[q]$, if $p \leq_{A} q$. The types $p, q$ are called independent if for any $\mathfrak{A} \in E_{T}, X \subseteq A$, don't have a place neither $p \leq_{A} q$, nor $q \leq_{A} p$. If $p$ and $q$ are independent, then we say that $[p]$ and $[q]$ are independent.

The following definition gives the concept of a basis among the above types.

Definition 25. The set $B=\left\{\left[p_{i}\right] \in S_{\nabla}^{(1)}[X] \mid i \in I\right\}$ is called base for $S_{\nabla}^{(1)}[X]$ if: 
(1) $\left[p_{i}\right]$ and $\left[q_{j}\right]$ independent for $i \neq j$;

(2) for any $[q] \in S_{\nabla}^{(1)}[X]$ and $\mathfrak{A} \in E_{T}, X \subseteq A$, exists $i \in I$ such that $\left[p_{i}\right] \leq_{A}[q]$.

Definition 26. The base of the theory $T$ is the base for $S_{\nabla}^{(1)}[\varnothing]$ (if it exists). The base $B$ of $T$ is called essential if for any $[p] \in B$ exists an essential type $q \in[p]$.

Definition 2\%. We will call the essential base of the types of Jonsson theory $T$ geometric if the following conditions are satisfied:

1) $\forall p \in S_{\nabla}^{(1)}(X)$, where $X \subseteq \mathcal{C}, \mathcal{C}$ as above and $(\mathcal{C}, c l)$ - J-geometry;

2) the concept of independence in the sense of geometry generated by a strongly minimal central type will coincide with the concept of independence $(\mathcal{C}, c l)-J$-geometry (coincidence of the concept of a base in terms of strong minimality, pregeometry and central types that form an essential base, wherein the orbits of the central types are their solutions in the semantic model).

Definition 28. Let $\mathfrak{M}$ be an existentially closed model of $T$ and $\varphi(\bar{x})$ be a non-algebraic $\nabla$-formula.

1. The set $\varphi(\mathfrak{M})$ is called $J$-minimal in $\mathfrak{M}$ if for all $\nabla$-formulas $\psi(\bar{x})$ the intersection $\varphi(\mathfrak{M}) \wedge \psi(\mathfrak{M})$ is either finite or cofinite in $\varphi(\mathfrak{M})$.

2. The formula $\varphi(\bar{x})$ is $J$-strongly minimal if $\varphi(\bar{x})$ defines a $J$-minimal set in all existentially closed extensions of $\mathfrak{M}$. In this case, we also call the definable set $\varphi(\mathfrak{M})$ is $J$-strongly minimal.

3. A non-algebraic type in $S_{\nabla}^{(1)}(T)$ containing a $J$-strongly minimal formula is called $J$-strongly minimal.

4. A Jonsson theory $T$ is $J$-strongly minimal if any its existentially closed model is $J$-strongly minimal.

One of the interesting questions in the classical model theory is the characterization of algebraically prime models. The complexity of this issue is that the concept of an algebraically prime model does not have a syntactic characterization, as is the case with a prime model. Our proposal is the use of Jonsson sets and the application of the rheostat principle. In the case of considering the Jonsson spectrum, all these problems make sense and their solution may be useful for solving related problems.

Recall the basic definitions associated with different types of prime and atomic models in the study of Jonsson theories.

The following definitions (29-34) are taken from [12].

Definition 29. The set $A$ is called $\left(\nabla_{1}, \nabla_{2}\right)-c l$ atomic in the theory $T$, if

1) $\forall a \in A, \exists \varphi \in \nabla_{1}$ such that for any formula $\psi \in \nabla_{2}$ follows that $\varphi$ is a complete formula for $\psi$ and $C \models \varphi(a)$;

2) $\operatorname{cl}(A)=M, M \in E_{T}$,

and obtained model $M$ is said to be $\left(\nabla_{1}, \nabla_{2}\right)-c l$ atomic model of theory $T$.

Definition 30 . The set $A$ is called weakly $\left(\nabla_{1}, \nabla_{2}\right)-c l$ is atomic in $T$, if

1) $\forall a \in A, \exists \varphi \in \nabla_{1}$ such that in $C \models \varphi(a)$ for any formula $\psi \in \nabla_{2}$ follow that $T \models(\varphi \rightarrow \psi)$ whenever $\psi(x)$ of $\nabla_{2}$ and $C=\psi(a)$;

2) $\operatorname{cl}(A)=M, M \in E_{T}$,

and obtained model $M$ is said to be weakly $\left(\nabla_{1}, \nabla_{2}\right)-c l$ atomic model of theory $T$.

It is easy to understand that definitions 29 and 30 are naturally generalized the notion of atomicity and weak atomicity to be $\nabla_{1}$-atom and weak $\nabla_{1}$-atom for any tuple of finite length from set $A$.

Let $i \in\{1,2\}, M_{i}=\operatorname{cl}\left(A_{i}\right)$, where $A_{i}=\left(\nabla_{1}, \nabla_{2}\right)$ is a $c l-$ atomic set. $a_{0}, \ldots, a_{n-1} \in A_{1}$, $b_{0}, \ldots, b_{n-1} \in A_{2}$.

Definition 31. (i) $\left(M_{1}, a_{0}, \ldots, a_{n-1}\right) \Rightarrow_{\nabla}\left(M_{2}, b_{0}, \ldots, b_{n-1}\right)$ means that for every formula $\varphi\left(x_{1}, \ldots, x_{n-1}\right)$ of $\nabla$, if $M_{1}=\varphi(\bar{a})$, then $M_{2}=\varphi(\bar{b})$.

(ii) $\left(M_{1}, \bar{a}\right) \equiv_{\nabla}\left(M_{2}, \bar{b}\right)$ means that $\left(M_{1}, \bar{a}\right) \Rightarrow_{\nabla}\left(M_{2}, \bar{b}\right)$ and $\left(M_{1}, \bar{b}\right) \Rightarrow_{\nabla}\left(M_{1}, \bar{a}\right)$.

Definition 32. A set $A$ will be called $\left(\nabla_{1}, \nabla_{2}\right)-c l$-algebraically prime in the theory $T$, if

1) If $A$ is $\left(\nabla_{1}, \nabla_{2}\right)-c l$-atomic set in $T$;

2) $\operatorname{cl}(A)=M, M \in A P_{T}$, 
and obtained model $M$ is said to be $\left(\nabla_{1}, \nabla_{2}\right)-c l$ algebraically prime model of theory $T$.

From the definition of an algebraically prime set in the theory $T$ follows that the Jonsson theory $T$ which has an algebraically prime set is automatically existentially prime. It is easy to understand that an example of such a theory is the theory of linear spaces.

Recall that the model $A$ of theory $T$ is called core if it is isomorphically embedded in any model of a given theory and this isomorphism exactly one.

Definition 33. The set $A$ will be called $\left(\nabla_{1}, \nabla_{2}\right)-c l$-core in the theory $T$, if

1) $A$ is $\left(\nabla_{1}, \nabla_{2}\right)$ a $c l$ - atomic set in the theory $T$;

2) $\operatorname{cl}(A)=M$, where $M$ is a core model of theory $T$

and obtained model $M$ is said to be $\left(\nabla_{1}, \nabla_{2}\right)-c l$ core model of theory $T$.

Definition 34. (a) A - $\left(\nabla_{1}, \nabla_{2}\right)$ - cl-atomic set in theory $T$ is said to be $\mathrm{A}-\left(\nabla_{1}, \nabla_{2}\right)-c l$ - $\Sigma$-nice-set in theory $T, \forall A^{\prime}: A^{\prime}-\left(\nabla_{1}, \nabla_{2}\right)-c l$-atomic set in theory $T$, if

1) $\operatorname{cl}(A)=M \in E_{T} \cap A P_{T}$

and obtained model $M$ is said to be $\left(\nabla_{1}, \nabla_{2}\right)-c l$ - $\Sigma$-nice model of theory $T$.

2) for all $a_{0}, \ldots, a_{n-1} \in A, b_{0}, \ldots, b_{n-1} \in A^{\prime}$, if $\left(M, a_{0}, \ldots, a_{n-1}\right) \Rightarrow_{\exists}\left(M^{\prime}, b_{0}, \ldots, b_{n-1}\right)$, then $\forall a_{n} \in A$, $\exists b_{n} \in A^{\prime}$ such that $\left(M, a_{0}, \ldots, a_{n}\right) \Rightarrow_{\exists}\left(M^{\prime}, b_{0}, \ldots, b_{n}\right)$, where $M^{\prime}=\operatorname{cl}\left(A^{\prime}\right)$.

(b) $A-\left(\nabla_{1}, \nabla_{2}\right)-c l-\Sigma^{*}$-nice-set in theory $T$ if the condition in (a) holds with ' $\Rightarrow \exists$ ' replaced both places it occurs by ' $\equiv \exists$ ' and obtained model $M$ is said to be $\left(\nabla_{1}, \nabla_{2}\right)-c l$ - $\Sigma^{*}$-nice model of theory $T$.

(c) $A-\left(\nabla_{1}, \nabla_{2}\right)-c l-\Delta$-nice set in theory $T$ if the condition in (a) holds with ' $\Rightarrow \Delta$ ' replaced both places it occurs by ' $\equiv{ }_{\Delta}$ ', where $\Delta \subseteq L, \Delta=\forall \cap \exists$.

and obtained model $M$ is said to be $\left(\nabla_{1}, \nabla_{2}\right)-c l-\Delta$-nice model of theory $T$.

\section{Principle of «rheostat»}

Let two countable models $A_{1}, A_{2}$ of some Jonsson theory $T$ be given. Moreover, $A_{1}$ is an atomic model in the sense of [13], and $X$ is $\left(\nabla_{1}, \nabla_{2}\right)-c l$-algebraically prime set of theory $T$ and $\operatorname{cl}(X)=A_{2}$. Since $\nabla_{1}=\nabla_{2}=L$, then $A_{1} \cong A_{2}$.

By the definition of $\left(\nabla_{1}, \nabla_{2}\right)$ - algebraic primeness of the set $X$, the model $A_{2}$ is both existentially closed and algebraically prime. Thus, the model $A_{2}$ is isomorphically embedded in the model $A_{1}$. Since by condition the model $A_{1}$ is countably atomic, then according to the Vaught's theorem, $A_{1}$ is prime, i.e. it is elementarily embedded in the model $A_{2}$. Thus, the models $A_{1}, A_{2}$ differ from each other only by the interior of the set $X$. This follows from the fact that any element of $a \in A_{2} \backslash X$ implements some main type, since $a \in \operatorname{cl}(X)$. That is, all countable atomic models in the sense of [13] are isomorphic to each other, then by increasing $X$ we find more elements that do not realize the main type and, accordingly, $\operatorname{cl}(X)$ is not an atomic model in the sense of [13]. Thus, the principle of rheostat is that, by increasing the power of the set $X$, we move away from the notion of atomicity in the sense of [13] and on the contrary, decreasing the power of the set $X$ we move away from the notion of atomicity in the sense of [14].

Let $A P C \in\{$ atomic, algebraically prime, core $\}$. Thus, by specifying the set $X$ as $\left(\nabla_{1}, \nabla_{2}\right)-c l-$ $A P C$, (where $A P C$ is a semantic property), we can also specify atomicity in the sense [14] in relation to atomicity in the sense of [13]. And accordingly, according to the principle of "rheostat" after the $A P C$ property is defined, we obtain the corresponding concepts of atomic models, the role of which is played $A_{2}$ from the principle of "rheostat".

One of the new directions in the study of the Jonsson spectrum is the study of model-theoretical properties of hybrids of the Jonsson classes of the spectrum under consideration. This problem is interesting in many respects, one of which is the existential model compatibility of a fragment of the algebraic construction of semantic models of these classes with the primordial theory.

The following definition 35 is taken from [15].

Let us define the essence of the operation of the symbol $\square$ for algebraic construction of models, which will be play important role in the definition of hybrids. Let $\square \in\left\{\cup, \cap, \times,+, \oplus, \prod_{F}\right.$, $\left.\prod_{U}\right\}$, where 
$\cup$-union, $\cap$-intersection, $\times$-Cartesian product, + -sum and $\oplus$-direct sum, $\prod_{F}$-filtered product and $\prod_{U}$ ultraproduct.

Definition 35. A hybrid of classes $[T]_{1},[T]_{2}$ is the class $[T]_{i} \in J S p(\mathcal{A}) / \bowtie$ if $T h_{\forall \exists}\left(C_{1} \square C_{2}\right) \in[T]_{i}$, we denote such hybrid as $H\left([T]_{1},[T]_{2}\right)$.

Note the following fact:

Fact 1. For the theory $H\left([T]_{1},[T]_{2}\right)$ in order to be Jonsson enough to be that $\left(C_{1} \boxminus C_{2}\right) \in E_{[T]_{i}}$, where $[T]_{i} \in J S p(\mathcal{A}) / \bowtie$.

\section{References}

1 Ешкеев А.Р. $J S p$-косемантичность и $J S B$-свойство абелевых групп / А.Р. Ешкеев, О.И. Ульбрихт // Siberian Electronic Mathematical Reports [Электронный ресурс]. - 2016. - Вып. 13. - C. 861-874. - Режим доступа: http://semr.math.nsc.ru.

2 Ешкеев A.P. JSp-косемантичность $R$ модулей / A.P. Ешкеев, О.И. Ульбрихт // Siberian electronics mathematical reports [Электронный pecypc]. - 2019. - Вып. 16. - C. 1233-1244. - Режим доступа: http://semr.math.nsc.ru.

3 Ешкеев А.Р. Йонсоновские теории и их классы моделей: моногр. / А.Р. Ешкеев, М.Т. Касыметова. - Караганда: Изд-во КарГУ, 2016. - 370 с.

4 Yeshkeyev A.R. Strongly minimal Jonsson sets and their properties / A.R. Yeshkeyev // Bulletin of the Karaganda University - Mathematics. - 2015. - Vol. 80. - No. 4. - P. 47-51.

5 Yeshkeyev A.R. Properties of lattices of the existential formulas of Jonsson fragments / A.R. Yeshkeyev, M.T. Kasymetova // Bulletin of the Karaganda University. Series Mathematics. - 2015. - Vol. 79. - No. 3. - P. 25-32.

6 Yeshkeyev A.R. The Properties of Similarity for Jonsson's Theories and Their Models / A.R. Yeshkeyev // Bulletin of the Karaganda University. Series Mathematics. - 2015. - Vol. 80. - No. 4. - P. 52-59.

7 Yeshkeyev A.R. $\Delta$-cl-atomic and prime sets / A.R. Yeshkeyev, A.K. Issayeva // Bulletin of the Karaganda University. Series Mathematics. - 2019. - Vol. 93. - No. 1. - P. 88-94.

8 Yeshkeyev A.R. Companions of the fragments in the Jonsson enrichment / A.R. Yeshkeyev // Bulletin of the Karaganda University. Series Mathematics. - 2017. - Vol. 85. - No. 1. - P. 41-45.

9 Yeshkeyev A.R. The properties of central types with respect to enrichment by Jonsson set / A.R. Yeshkeyev // Bulletin of the Karaganda University. Series Mathematics. - 2017. - Vol. 85. - No. 1. - P. 36-40.

10 Yeshkeyev A.R. Criterion for the cosemanticness of the Abelian groups in the enriched signature / A.R. Yeshkeyev, M.T. Kassymetova, O.I. Ulbrikht // Bulletin of the Karaganda University. Series Mathematics. - 2018. - Vol. 89. - No. 1. - P. 49-60.

11 Yeshkeyev A.R. The J-minimal sets in the hereditary theories / A.R. Yeshkeyev, M.T. Omarova, G.E. Zhumabekova // Bulletin of the Karaganda University. Series Mathematics. - 2019. Vol. 94. - No. 2. - P. 92-98.

12 Yeshkeyev A.R. The atomic definable subsets of semantic model / A.R. Yeshkeyev, N.M. Mussina, A.K. Issayeva // Bulletin of the Karaganda University. Series Mathematics. - 2019. - Vol. 94. - No. 2. - P. 84-91.

13 Vaught R. Denumerable models of complete theories in Infinitistic Methode / R. Vaught // Pergamon. - London, 1961. - P. 303-321.

14 Baldwin J.T. Algebraically prime models / J.T. Baldwin, D.W. Kueker // Ann. Math. Logic. 1981. - 20. - P. 289-330. 
15 Yeshkeyev A.R. Hybrids of classes from Jonsson spectrum / A.R. Yeshkeyev, N.M. Mussina // The Bulletin of Symbolic Logic. - 2019. - Vol. 25. - No. 4. - P. 523.

\author{
A.P. Ешкеев
}

\title{
Йонсондық спектрдің модельді-теоретикалық сұрақтары
}

\begin{abstract}
Макалада йонсондық спектрді зерттеу аясында жаңа ұғымдар анықталған. Индуктивті, жалпы айтқанда, толық емес теориялар класындағы элементарлық эквиваленттіліктің жалпылауы болып табылатын косемантикалық ұғымына қатысты спектр қарастырылған. Сондай-ақ, йонсондық спектрдің көмегімен йонсондық теориялар мен олардың модельдерінің кластарын зерттеудің нақты бағыттары анықталды, атап айтқанда индуктивтік теориялардың жеткілікті кең ішкі классын анықтайтын және толықтық, модельді және модельді компаньон сияқты модельдер теориясының классикалық сұрақтарын зерттеу болып табылады. Сондықтан, йонсондық спектрдің модельді-теоретикалық қасиеттерін зерттегенде, біз элементарлық эквиваленттік тұжырымдамасынан косемантикалық тұжырымдамасына, сонымен қатар теориялар мен модельдерге көшкенде табиғи түрде пайда болатын сол ұғымдардың анықтамасын нақтылауымыз қажет. Сонымен бірге, йонсондық спектрдің кейбір модельді-теоретикалық қасиеттері қарастырылған. Йонсондық спектрге қатысты барлық берілген есептердің мағынасы бар және олардың шешімдерін шығару пайдалы болуы мүмкін, өйткені бұл мәселе йонсондық теориялар саласында белсенді түрде зерттелген.
\end{abstract}

Kiлm сөздер: йонсондық теория, йонсондық спектр, косеманттылық, толықтық, ұқсастылық.

\author{
A.P. Ешкеев
}

\section{Теоретико-модельные вопросы йонсоновского спектра}

В статье определены новые понятия в рамках изучения йонсоновских спектров. Рассмотрен спектр относительно понятия косемантичности, который является обобщением элементарной эквивалентности в классе индуктивных, вообще говоря, неполных теорий. Также с помощью йонсоновских спектров изучены актуальные направления йонсоновских теорий и их классов моделей, а именно классических вопросов теории моделей, таких как полнота модели, компаньон модели в рамках упомянутых выше условий, которые определяют довольно широкий подкласс индуктивных теорий и какие называются йонсоновскими теориями. По этой причине при изучении теоретико-модельных свойств йонсоновских спектров мы нуждаемся в уточнении определений тех понятий, которые естественным образом возникают при переходе от понятия элементарной эквивалентности к понятию косемантичности, причем, как теорий, так и моделей. Рассмотрены некоторые теоретико-модельные свойства йонсоновских спектров. В случае рассмотрения йонсоновского спектра все задачи, которые заданы в данной работе, имеют смысл, и их решение может оказаться полезным для решения смежных задач, потому что данная проблематика является активно изучаемой в области йонсоновских теорий.

Ключевые слова: йонсоновская теория, йононовский спектр, косемантичность, полнота, подобие.

\section{References}

1 Yeshkeyev, A.R. \& Ulbrikht, O.I. (2016). JSp-kosemantichnost i JSB-svoistvo abelevykh hrupp [JSp-cosemanticnes and JSB property of abelian groups]. Siberian Electronic Mathematical Reports. Retrieved from http://semr.math.nsc.ru. [in Russian].

2 Yeshkeyev, A.R. \& Ulbrikht, O.I. (2019). JSp-kosemantichnost R-modulei [JSp-cosemanticness of R-modules]. Siberian Electronic Mathematical Reports. Retrieved from http://semr.math.nsc.ru. [in Russian]. 
3 Yeshkeyev, A.R. \& Kassymetova, M.T. (2016). Ionsonovskie teorii $i$ ikh klassy modelei /Jonsson theories and their classes of models]. Karaganda: Izdatelstvo Karahandinskoho hosudarstvennoho universiteta [in Russian].

4 Yeshkeyev, A.R. (2015). Strongly minimal Jonsson sets and their properties. Bulletin of the Karaganda University. Series Mathematics, Vol. 80, 4, 47-51.

5 Yeshkeyev, A.R. \& Kasymetova, M.T. (2015). Properties of lattices of the existential formulas of Jonsson fragments. Bulletin of the Karaganda University. Series Mathematics, Vol. 79, 3, 25-32.

6 Yeshkeyev, A.R. (2015). The Properties of Similarity for Jonsson's Theories and Their Models. Bulletin of the Karaganda University. Series Mathematics, Vol. 80, 4, 52-59.

7 Yeshkeyev, A.R. \& Issayeva, A.K. (2019). $\Delta$-cl-atomic and prime sets. Bulletin of the Karaganda University. Series Mathematics, Vol. 93, 1, 88-94.

8 Yeshkeyev, A.R. (2017). Companions of the fragments in the Jonsson enrichment. Bulletin of the Karaganda University. Series Mathematics, Vol. 85, 1, 41-45.

9 Yeshkeyev, A.R. (2017). The properties of central types with respect to enrichment by Jonsson set. Bulletin of the Karaganda University. Series Mathematics, Vol. 85, 1, 36-40.

10 Yeshkeyev, A.R., Kasymetova, M.T. \& Ulbrikht, O.I. (2018). Criterion for the cosemanticness of the Abelian groups in the enriched signature. Bulletin of the Karaganda University. Series Mathematics, Vol. 89, 1, 49-60.

11 Yeshkeyev, A.R., Omarova M.T. \& Zhumabekova G.E. (2019). The J-minimal sets in the hereditary theories. Bulletin of the Karaganda University. Series Mathematics, Vol. 94, 2, 92-98.

12 Yeshkeyev, A.R., Issayeva, A.K., \& Mussina, N.M. (2019). The atomic definable subsets of semantic model. Bulletin of the Karaganda University. Series Mathematics, Vol. 94, 2, 84-91.

13 Vaught, R. (1961). Denumerable models of complete theories in Infinitistic Methode. Pergamon. London.

14 Baldwin, J.T. \& Kueker, D.W. (1981). Algebraically prime models. Ann. Math. Logic., 20, 289330.

15 Yeshkeyev, A.R., \& Mussina, N.M. (2019). Hybrids of classes from Jonsson spectrum. The Bulletin of Symbolic Logic, - Vol. 25, 4, 523. 